\title{
Transient Global Amnesia and Brain Tumour: Chance Concurrence or Aetiological Association? Case Report and Systematic Literature Review
}

\author{
Phil Milburn-McNulty Andrew J. Larner \\ Cognitive Function Clinic, Walton Centre for Neurology and Neurosurgery, Liverpool, UK
}

\section{Key Words}

Amnesia · Brain tumour - Epilepsy · Transient epileptic amnesia · Transient global amnesia

\begin{abstract}
We report a patient presenting with episodes of transient amnesia, some with features suggestive of transient global amnesia (TGA), and some more reminiscent of transient epileptic amnesia. Investigation with neuroimaging revealed an intrinsic lesion in the right amygdala, with features suggestive of low-grade neoplasia. We undertook a systematic review of the literature on TGA and brain tumour. Fewer than 20 cases were identified, some of which did not conform to the clinical diagnostic criteria for TGA. Hence, the concurrence of brain tumour and TGA is very rare and of doubtful aetiological relevance. In some brain tumourassociated cases, epilepsy may be masquerading as TGA.

(C) 2015 S. Karger AG, Basel
\end{abstract}

\section{Introduction}

Syndromes of transient amnesia may broadly be conceptualised as idiopathic, epileptic or psychological in origin. Although there are some clinical features which may be helpful in distinguishing these syndromes, in clinical practice it may sometimes be difficult to tease them apart. Abnormalities on brain imaging may also complicate the interpretation.

Transient global amnesia (TGA) was first reported as such in the 1950s [1, 2]. The typical clinical features are short-lasting $(<24 \mathrm{~h})$ attacks of anterograde amnesia with otherwise normal cognition in the absence of any demonstrable focal neurological deficit. The differen-

KARGER 125/s $\quad \begin{aligned} & \text { A.J. Larner } \\ & \text { Cognitive Function Clinic } \\ & \text { Walton Centre for Neurology and Neurosurgery } \\ & \text { Lower Lane, Fazakerley, Liverpool, L9 7LJ (UK) } \\ & \text { E-Mail a.larner@thewaltoncentre.nhs.uk }\end{aligned}$


Milburn-McNulty and Larner: Transient Global Amnesia and Brain Tumour: Chance Concurrence or Aetiological Association?

tial diagnosis of TGA includes transient epileptic amnesia (TEA), characterised by brief (ca. $1 \mathrm{~h}$ ) attacks of impaired memory, most commonly occurring on waking from sleep [3]. Diagnostic criteria for TGA have been suggested (table 1) [4].

The aetiology of TGA is still unclear. One theory suggests that TGA is a migraine-type phenomenon, another that it reflects a brief interruption of vascular perfusion of memoryeloquent structures in the medial temporal lobe, for which some evidence has accrued from neuroimaging studies finding focal hippocampal signal changes occurring over a time scale similar to that of vascular lesions [5]. In the vast majority of cases, TGA is not associated with structural abnormalities on standard brain imaging techniques [6]. However, occasional cases of TGA associated with brain tumour have been reported.

\section{Case Report}

A 66-year-old right-handed man was referred to the cognitive neurology clinic following 4 episodes of transient amnesia over a 6-month period. Each episode occurred within hours of strenuous physical exercise. In the first episode, he returned home from a bicycle ride confused about the route he had taken. The second event occurred following a walk up a steep incline. The third event occurred the day after a strenuous bike ride when the patient awoke in the morning confused as to where he was and what the plan for the day was. This confusion recurred the same day following a post-prandial nap. All the events were witnessed by the patient's wife who noted repetitive questioning to be a feature in each. All lasted between $30 \mathrm{~min}$ and $2 \mathrm{~h}$ with complete recovery. No other accompanying focal neurological symptoms were noted during the attacks.

The patient's past medical history was unremarkable: he had undergone two hip replacements but was otherwise fit and well. There was no history of recent head injury or epilepsy. He consumed 12 units of alcohol per week and was a lifelong non-smoker. He had previously worked as a project manager for a bank and regularly enjoyed cycling, golf and walking. There was no family history of any cognitive disorder.

Neurological examination in the clinic was unremarkable. On cognitive testing, he scored $0 / 28$ on the Six-Item Cognitive Impairment Test (normal) and 28/30 on the MiniMental State Examination.

A diagnosis of TGA, concordant with suggested diagnostic criteria [4], was thought likely on the basis of the history, at least for the first 2 episodes. However, because of the recurrent nature and brevity of the attacks and events emerging on waking from sleep, all features more suggestive of TEA [3], further investigations were undertaken.

Magnetic resonance (MR) brain imaging showed some very subtle but unequivocal signal change in the right amygdala (fig. 1), the nature of which was uncertain. Diffusionweighted imaging was normal with no restriction of diffusion and no disruption of limbic white matter tracts or adjacent temporal fibre bundles. Single-voxel MR spectroscopy of the affected area showed elevated choline resonance (NAA:Cho ratio $=0.64$ ). Repeat MR brain imaging performed 2, 6 and 12 months later showed unchanged appearances. The imaging findings were thought most likely to indicate low-grade neoplasia, or possibly dysplasia or gliosis. Initial concerns that the imaging findings might reflect limbic encephalitis or frequent epileptic seizures ('epileptic crisis') were refuted by the clinical phenotype and the stability of the imaging changes, without evidence of focal atrophy.

The standard electroencephalogram (EEG) was within normal limits, but sleep-deprived EEG showed excess slow waves over the right temporal region and one prolonged run of slow waves followed by brief high-amplitude sharp wave bursts. 
Milburn-McNulty and Larner: Transient Global Amnesia and Brain Tumour: Chance Concurrence or Aetiological Association?

Because of the clinical and radiological stability of the patient, a biopsy of the lesion was not thought to be indicated. The patient continues to be followed up with regular surveillance MR brain imaging and has had further occasional amnesic episodes on waking from sleep. For these episodes, prophylactic anti-epileptic drug therapy has been offered but the patient has declined this on the basis of the infrequency of the events and concerns about possible adverse effects of medication. Repeat Mini-Mental State Examination 12 months after initial presentation was stable (score 29/30).

In light of our experience with this case, we undertook a systematic review to identify reported cases of TGA and brain tumour. (Although the diagnosis of tumour was not definitively established in our case, it was our provisional diagnosis since it was the most likely on the basis of the investigation findings, and the system of surveillance initiated was that employed at our centre for suspected tumour cases.) A systematic literature search was undertaken using several abstract databases (Medline, from 1966 until the end of 2013; PsycINFO, from 1887 until the end of 2013, and Embase, from 1980 until the end of 2013). Five full-text collections (Science Direct, Ingenta Select, Ovid Full Text, Blackwell Online and Wiley Interscience) and the abstract database Web of Knowledge (4.0, ISI) were searched. The following search terms were used: 'transient amnesia or TGA or TEA' and 'tumour or glioma or meningioma or cancer or dysplasia or gliosis'.

The findings, including the current case, amounted to 20 examples (table 2) [6-23]. This has extended the previous narrative reviews of TGA and tumour by Dinca et al. [23] and Daniel [24]. No cases of transient amnesia associated with either dysplasia or gliosis were identified, although pathological evidence of gliosis may be found in some cases of epilepsyrelated amnesia; however, the latter is persistent rather than transient [25].

The only study reporting data which might address the question of the frequency of TGA associated with brain tumour was that of Agosti et al. [6]: in a series of 130 patients meeting diagnostic criteria for TGA and undergoing investigation with modern brain imaging modalities, 13 patients had structural brain lesions, of whom 2 (1.5\%) had falx meningiomas. No case of brain tumour was encountered in the series $(n=114)$ of Hodges and Warlow [4]. In a consecutive series of 24 TGA cases seen in our clinic [26-28], this is the first case encountered in which a brain tumour has been found.

Many of the reports [7-19] predated widely accepted clinical diagnostic criteria for TGA [4], and for this reason, some cases might be excluded as not conforming to criteria. For example, in one case, the amnesic episode lasted more than $24 \mathrm{~h} \mathrm{[7],} \mathrm{and} \mathrm{in} \mathrm{another,} \mathrm{progres-}$ sive memory problems followed a generalised tonic clonic seizure [11]; in yet another case, the patient was reported to have 6 episodes of TGA and on examination had bilateral papilloedema [16] (criticised as unlikely to be TGA by Hodges [29]). Caplan [30] previously criticised the case reported by Meador et al. [13] on the grounds that the reported clinical features (two short-lasting and unobserved episodes of loss of awareness) did not suggest TGA.

The clinical features of TGA cases with and without neuroimaging evidence of structural brain lesions are said to be the same [6]. However, in the current case and one previous report [22], both associated with medial temporal lobe pathology, there have been clinical features suggestive of both TGA and TEA.

Various tumour locations were reported. Some were located distant from memoryeloquent structures, such as falx meningiomas $[6,17]$ and pituitary tumour [8], one associated with pituitary haemorrhage [21]. On the other hand, tumours located within or in proximity to memory-eloquent structures, such as the temporal lobe [13,16, 22, 23], limbic system [9], hippocampus [11] or amygdala (current case), were also reported.

Most reported cases of TGA and brain tumour had either histologically proven primary brain tumours $[6-8,10,11,13,20-23]$ or were presumed to be primary brain tumours 
Milburn-McNulty and Larner: Transient Global Amnesia and Brain Tumour: Chance Concurrence or Aetiological Association?

where histological analysis was not performed. Two cases were secondary tumours, from a bladder transitional cell carcinoma [12] and a lung primary [22], respectively.

If the absence of EEG abnormalities is accepted as a TGA diagnostic criterion (EEG is very seldom recorded during an amnesic event) [28], 6 of the reported cases might be excluded on the basis of abnormalities on interval EEG studies [8-10, 13, 22, 23]. (EEG was not reported, presumably not undertaken or normal in at least 6 other cases $[6,14,19-21]$.) It is possible that some of these cases might have been instances of TEA rather than of TGA, although EEG abnormalities are only seen in about one third of TEA cases on interval EEG [3]. In his review, Daniel [24] stated his belief that the cases reported by Hartley et al. [8], Shuping et al. [11] and Honma and Nagao [21] are likely to be instances of TEA rather than of TGA, and possibly also the case of Meador et al. [13].

\section{Discussion}

What is the clinical significance of these reports of TGA and brain tumour? Some reports fail to meet the clinical criteria for TGA whereas others have features which might be more in keeping with TEA. In some cases, the finding of a tumour is unlikely to be any more than chance concurrence, based on tumour location distant from memory-eloquent structures, whereas other tumour locations are more obviously of possible pathophysiological relevance. Such localised neoplastic lesions might result in abnormal electrical activity within medial temporal lobe networks, hence producing TEA-like events, and also compromise medial temporal lobe blood supply, for example in association with exercise, and hence predispose to typical TGA-like events. In other words, the tumour might lower the threshold for the clinical manifestation of vascular and/or epileptiform events. Alternatively, it is recognised that a subset of 'pure TGA' patients, largely identifiable because of atypically brief or recurrent attacks, develop epilepsy and/or respond to antiepileptic medication [4]. These features - short duration of symptoms $(<2 \mathrm{~h})$, stereotyped semiology, and high recurrence rate - are all typical of TEA as opposed to TGA. Hence, all the reported cases of tumourrelated TGA might in fact be instances of TEA.

In summary, the evidence suggests that the concurrence of brain tumour and TGA is extremely rare. Although some authors accept that brain tumour may be associated with or imitate TGA [24, 31], on the basis of our experience and the systematic literature review, we doubt if a tumour is ever aetiologically significant in TGA, since the reported cases could all be TEA, in some instances 'masquerading' as TGA [32]. Although some authors advocate brain imaging in all TGA cases to exclude a symptomatic lesion [6], on the basis of this review, we would argue that neuroimaging should be reserved for those TGA patients with atypical clinical features, such as recurrent episodes and/or episodes clinically more suggestive (in terms of their brevity and stereotyped nature) of TEA.

\section{References}

Bender MB: Syndrome of isolated episode of confusion with amnesia. J Hillside Hosp 1956;5:212-215. Guyotat MM, Courjon J: Les ictus amnésiques. J Med Lyon 1956;37:697-701.

-3 Zeman A, Butler C, Hodges J, Kapur N: The syndrome of transient epileptic amnesia; in Zeman A, Kapur N, Jones-Gotman M (eds): Epilepsy and Memory. Oxford, Oxford University Press, 2012, pp 139-159.

-4 Hodges JR, Warlow CP: Syndromes of transient amnesia: towards a classification. A study of 153 cases. J Neurol Neurosurg Psychiatry 1990;53:834-843.

5 Bartsch T, Deuschl G: Transient global amnesia: functional anatomy and clinical implications. Lancet Neurol 2010;9:205-214. 
Milburn-McNulty and Larner: Transient Global Amnesia and Brain Tumour: Chance Concurrence or Aetiological Association?

6 Agosti C, Borroni B, Akkawi NM, De Maria G, Padovani A: Transient global amnesia and brain lesions: new hints into clinical criteria. Eur J Neurol 2008;15:981-984.

$>7$ Aimard G, Trillet M, Perroudou C, Tommasi M, Carrier H: Ictus amnésique symptomatique d'un glioblastome intéressant le trigone. Rev Neurol 1971;124:392-396.

-8 Hartley TC, Heilman KM, Garcia-Bengochea F: A case of transient global amnesia due to a pituitary tumor. Neurology 1974;24:998-1000.

-9 Boudin G, Pepin B, Mikol J, Haguenau M, Vernant JC: Gliome du système limbique postérieur, révélé par une amnésie globale transitoire. Observation anatomo-clinique d'un cas. Rev Neurol 1975;131:157-163.

10 Lisak RP, Zimmerman RA: Transient global amnesia due to a dominant hemisphere tumor. Arch Neurol 1977;34:317-318.

11 Shuping JR, Toole JF, Alexander E Jr: Transient global amnesia due to a glioma in the dominant hemisphere. Neurology 1980;30:88-90.

-12 Findler G, Feinsod M, Lijovetzky G, Hadani M: Transient global amnesia associated with a single metastasis in the non-dominant hemisphere. Case report. J Neurosurg 1983;58:303-305.

13 Meador KM, Adams RJ, Flanigin HF: Transient global amnesia and meningioma. Neurology 1985;35:769771.

14 Riva C, Leiva C, Gobernado JM, Gimeno A: Amnesia global transitoria asociada a un meningioma del lobulo frontal. Med Clin (Barc) 1985;84:81.

15 Collins MP, Freeman JW: Meningioma and transient global amnesia: another report. Neurology 1986;36:594.

16 Matias-Guiu J, Colomer R, Segura A, Codina A: Cranial CT scan in transient global amnesia. Acta Neurol Scand 1986;73:298-301.

17 Araga S, Fukada M, Kagimoto H, Imagawa T, Takahashi K: Transient global amnesia and falcotentorial meningioma - a case report. Jpn J Psychiatry Neurol 1989;43:201-203.

-18 Cattaino G, Pomes A, Querin F, Cecotto C: Ethmoidal meningioma revealed by transient global amnesia. Ital J Neurol Sci 1989;10:187-191.

19 Po HL, Hseuh IH: Transient global amnesia associated with a right sphenoid ridge meningioma: a case report. Zhonghua Yi Xue Za Zhi (Taipei) 1990;46:113-116.

20 Sorenson EJ, Silbert PL, Benarroch EE, Jack CR, Parisi JE: Transient amnesic syndrome after spontaneous haemorrhage into a hypothalamic pilocytic astrocytoma. J Neurol Neurosurg Psychiatry 1995;58:761-763. Honma Y, Nagao S: Hemorrhagic pituitary adenoma manifesting as transient global amnesia. Neurol Med Chir (Tokyo) 1996;36:234-236.

22 Huang CF, Pai MC: Transient amnesia in a patient with left temporal tumor. Symptomatic transient global amnesia or an epileptic amnesia? Neurologist 2008;14:196-200.

-23 Dinca EB, Carron R, Gay E: Transient global amnesia as a revealing sign of giant transtentorial meningioma. Case report and review of the literature. J Nerv Ment Dis 2011;199:416-418.

24 Daniel BT: Transient global amnesia. Print version and ebook. Amazon, 2012, pp 186-191, 204-205, 208, 245.

25 Butler C, Kapur N, Zeman A, Weller R, Connelly A: Epilepsy-related long-term amnesia: anatomical perspectives. Neuropsychologia 2012;50:2973-2980.

Larner AJ: Transient global amnesia in the district general hospital. Int J Clin Pract 2007;61:255-258. Larner AJ: Amnesia as a sex-related adverse event. Br J Hosp Med 2011;72:292-293. Ung KYC, Larner AJ: Transient amnesia: epileptic or global? A differential diagnosis with significant implications for management. QJ Med 2014;107:915-917.

29 Hodges JR: Transient Amnesia. Clinical and Neuropsychological Aspects. London, WB Saunders, 1991, p 30. Caplan LR: Transient global amnesia: criteria and classification. Neurology 1986;36:441.

Roach ES: Transient global amnesia: look at mechanisms not causes. Arch Neurol 2006;63:1338-1339.

Hodges JR, Warlow CP: The aetiology of transient global amnesia. A case-control study of 114 cases with prospective follow-up. Brain 1990;113:639-657. 
Milburn-McNulty and Larner: Transient Global Amnesia and Brain Tumour: Chance Concurrence or Aetiological Association?

Table 1. Diagnostic criteria for definite TGA [4]

- Attacks must be witnessed and information available from a capable observer who was present for most of the attack

- $\quad$ There must be clear-cut anterograde amnesia during the attack

- Clouding of consciousness and loss of personal identity must be absent and the cognitive impairment limited to amnesia (i.e., no aphasia, apraxia, etc.)

- There should be no accompanying focal neurological symptoms during the attack and no significant neurological signs afterwards

- $\quad$ Epileptic features must be absent

- $\quad$ Attacks must resolve within $24 \mathrm{~h}$

- $\quad$ Patients with recent head injury or active epilepsy (i.e., remaining on medication or with 1 seizure in the past 2 years) are excluded 
Milburn-McNulty and Larner: Transient Global Amnesia and Brain Tumour: Chance

Concurrence or Aetiological Association?

Table 2. Summary of publications from a systematic review reporting cases of TGA in association with brain tumour

\begin{tabular}{|c|c|c|c|c|c|c|c|c|c|}
\hline Reference & $\begin{array}{l}\text { Dominant } \\
\text { hand }\end{array}$ & $\begin{array}{l}\text { Age at } \\
\text { onset, } \\
\text { years }\end{array}$ & Gender & Histology & Location & Primary & Co-morbidities & EEG findings & Notes \\
\hline $\begin{array}{l}\text { Aimard et al. } \\
\text { [7] }\end{array}$ & $\begin{array}{l}\text { Not } \\
\text { stated }\end{array}$ & 65 & Female & Glioblastoma & $\begin{array}{l}\text { 'Trigone and } \\
\text { diffuse' }\end{array}$ & Yes & $\begin{array}{l}\text { Syphilitic meningo- } \\
\text { encephalitis; } \\
\text { Herxheimer reaction }\end{array}$ & Normal & Initial episode $>24 \mathrm{~h}$ \\
\hline $\begin{array}{l}\text { Hartley et al. } \\
\text { [8] }\end{array}$ & $\begin{array}{l}\text { Not } \\
\text { stated }\end{array}$ & 62 & Male & $\begin{array}{l}\text { Chromophobe } \\
\text { adenoma }\end{array}$ & Pituitary & Yes & None reported & $\begin{array}{l}\text { EEG 1: temporal high- } \\
\text { amplitude slow waves; } \\
\text { EEG 2: normal }\end{array}$ & $\begin{array}{l}\text { Additional, non-transient } \\
\text { memory deficit reported }\end{array}$ \\
\hline $\begin{array}{l}\text { Boudin et al. } \\
{[9]}\end{array}$ & $\begin{array}{l}\text { Not } \\
\text { stated }\end{array}$ & 73 & Female & Glioma & $\begin{array}{l}\text { Posterior limbic } \\
\text { system, } \\
\text { bilateral }\end{array}$ & Yes & Nil & $\begin{array}{l}\text { EEG 1: left temporal slow } \\
\text { waves; EEG 2: diffuse } \\
\text { bilateral synchronous slow } \\
\text { anomalies }\end{array}$ & $\begin{array}{l}\text { Preceded Korsakoff's } \\
\text { syndrome } 3 \text { months later }\end{array}$ \\
\hline $\begin{array}{l}\text { Lisak and } \\
\text { Zimmerman } \\
{[10]}\end{array}$ & Right & 70 & Male & Unknown & $\begin{array}{l}\text { Left temporal- } \\
\text { parietal }\end{array}$ & Unknown & $\begin{array}{l}\text { Atherosclerotic } \\
\text { coronary artery } \\
\text { disease }\end{array}$ & $\begin{array}{l}\text { EEG 1: normal; EEG2: left } \\
\text { parieto-temporal spike and } \\
\text { slow waves }\end{array}$ & \\
\hline $\begin{array}{l}\text { Shuping et al. } \\
\text { [11] }\end{array}$ & Right & 60 & Male & Glioblastoma & Left hippocampus & Yes & $\begin{array}{l}\text { Myocardial infarction, } \\
\text { hypertension }\end{array}$ & Normal & $\begin{array}{l}\text { Progressive memory } \\
\text { problems; } 1 \text { generalised } \\
\text { tonic clonic seizure }\end{array}$ \\
\hline $\begin{array}{l}\text { Findler et al. } \\
{[12]}\end{array}$ & Right & 67 & Male & Metastasis & $\begin{array}{l}\text { Non-dominant } \\
\text { hemisphere }\end{array}$ & $\begin{array}{l}\text { No, bladder } \\
\text { primary }\end{array}$ & $\begin{array}{l}\text { Transitional cell } \\
\text { carcinoma bladder }\end{array}$ & Normal & \\
\hline $\begin{array}{l}\text { Meador et al. } \\
\text { [13] }\end{array}$ & $\begin{array}{l}\text { Not } \\
\text { stated }\end{array}$ & 47 & Female & Meningioma & $\begin{array}{l}\text { Right temporal } \\
\text { lobe }\end{array}$ & Yes & None reported & $\begin{array}{l}2 \text { standard EEG: normal; } \\
\text { sleep-deprived EEG: bilateral } \\
\text { mid-/post-temporal } \\
\text { discharges }\end{array}$ & \\
\hline Riva et al. [14] & $\begin{array}{l}\text { Not } \\
\text { stated }\end{array}$ & 64 & Female & Meningioma & Olfactory bulb & Yes & $\begin{array}{l}2 \text { episodes, age } 64 \\
\text { and } 71\end{array}$ & None reported & \\
\hline $\begin{array}{l}\text { Collins and } \\
\text { Freeman [15] }\end{array}$ & $\begin{array}{l}\text { Not } \\
\text { stated }\end{array}$ & 61 & Male & Meningioma & $\begin{array}{l}\text { Right parietal } \\
\text { region }\end{array}$ & Yes & Hypertension & Normal & \\
\hline $\begin{array}{l}\text { Matias-Guiu } \\
\text { et al. [16] }\end{array}$ & $\begin{array}{l}\text { Not } \\
\text { stated }\end{array}$ & $\begin{array}{l}\text { Not } \\
\text { stated }\end{array}$ & Male & Unknown & $\begin{array}{l}\text { Right temporal } \\
\text { lobe }\end{array}$ & Unknown & & None reported & $\begin{array}{l}6 \text { episodes; bilateral } \\
\text { papilloedema; more } \\
\text { likely TEA? }\end{array}$ \\
\hline $\begin{array}{l}\text { Araga et al. } \\
\text { [17] }\end{array}$ & Right & 59 & Female & Meningioma & $\begin{array}{l}\text { Falcotentorial } \\
\text { region }\end{array}$ & Yes & None reported & Normal & \\
\hline $\begin{array}{l}\text { Cattaino et al. } \\
\text { [18] }\end{array}$ & Left & 47 & Female & Meningioma & $\begin{array}{l}\text { Right frontal lobe, } \\
\text { ethmoidal }\end{array}$ & Yes & Nil & Normal & \\
\hline $\begin{array}{l}\text { Po and Hseuh } \\
\text { [19] }\end{array}$ & $\begin{array}{l}\text { Not } \\
\text { stated }\end{array}$ & 65 & Female & Meningioma & $\begin{array}{l}\text { Right sphenoid } \\
\text { ridge }\end{array}$ & Yes & None reported & None reported & $\begin{array}{l}\text { Developed permanent } \\
\text { loss of recent memory }\end{array}$ \\
\hline $\begin{array}{l}\text { Sorenson et al. } \\
{[20]}\end{array}$ & $\begin{array}{l}\text { Not } \\
\text { stated }\end{array}$ & 58 & Female & Astrocytoma & Right hypothalamus & Yes & Nil & None reported & $\begin{array}{l}\text { Haemorrhage pilocytic } \\
\text { astrocytoma }\end{array}$ \\
\hline $\begin{array}{l}\text { Honma and } \\
\text { Nagao [21] }\end{array}$ & Right & 68 & Female & Adenoma & $\begin{array}{l}\text { Pituitary, complicated } \\
\text { by haemorrhage }\end{array}$ & Yes & Hypertension & None reported & $\begin{array}{l}\text { Haemorrhagic prolactin- } \\
\text { producing tumour }\end{array}$ \\
\hline $\begin{array}{l}\text { Huang and Pai } \\
{[22]}\end{array}$ & Right & 67 & Male & Unknown & $\begin{array}{l}\text { Left medial temporal } \\
\text { lobe }\end{array}$ & $\begin{array}{l}\text { No, lung } \\
\text { primary }\end{array}$ & Migraine & $\begin{array}{l}\text { Isolated wicket temporal } \\
\text { spikes in the left mesial } \\
\text { temporal area }\end{array}$ & TEA rather than TGA? \\
\hline $\begin{array}{l}\text { Agosti et al. } \\
\text { [6] (2 cases) }\end{array}$ & $\begin{array}{l}\text { Not } \\
\text { stated }\end{array}$ & $\begin{array}{l}\text { Not } \\
\text { stated }\end{array}$ & $\begin{array}{l}\text { Not } \\
\text { stated }\end{array}$ & Meningioma & Falx & Yes & None reported & None reported & \\
\hline $\begin{array}{l}\text { Dinca et al. } \\
\text { [23] }\end{array}$ & $\begin{array}{l}\text { Not } \\
\text { stated }\end{array}$ & 75 & Female & $\begin{array}{l}\text { Meningioma, } \\
\text { WHO type } 1\end{array}$ & $\begin{array}{l}\text { Right transtentorial - } \\
\text { from cerebellum to } \\
\text { temporal lobe }\end{array}$ & Yes & $\begin{array}{l}\text { Asthma, depression, } \\
\text { cholecystectomy, } \\
\text { previously resected } \\
\text { malignant colonic } \\
\text { polyp }\end{array}$ & $\begin{array}{l}\text { Right-sided temporal slow } \\
\text { waves consistent with the } \\
\text { presence of an intracranial } \\
\text { mass }\end{array}$ & \\
\hline $\begin{array}{l}\text { Milburn- } \\
\text { McNulty } \\
\text { and Larner, } \\
2015\end{array}$ & Right & 66 & Male & Unknown & Right amygdala & Yes & Nil & Normal & TEA rather than TGA? \\
\hline
\end{tabular}




\section{Case Reports in Neurology}

Case Rep Neurol 2015;7:18-25

DOI: $10.1159 / 000371840$

2015 S. Karger AG, Basel www.karger.com/crn

Milburn-McNulty and Larner: Transient Global Amnesia and Brain Tumour: Chance Concurrence or Aetiological Association?

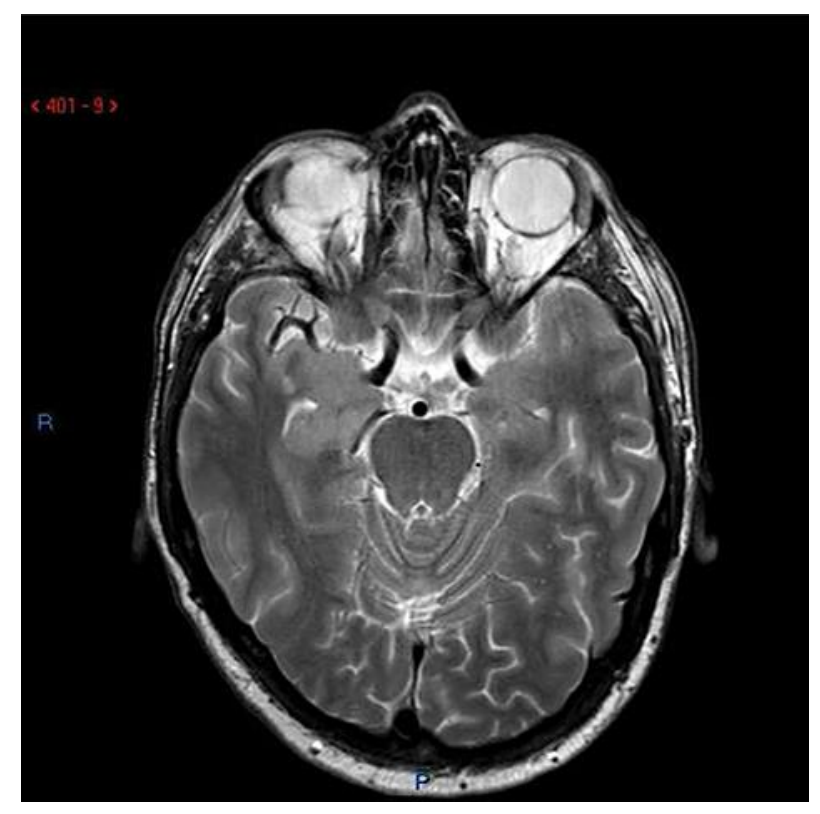

Fig. 1. Axial MR brain image showing subtle signal change in the right as compared to the left amygdala. 